\title{
Public Agrarian Policies and Food Security in Cameroon: Problems and Challenges towards Agricultural Development
}

\author{
A. Daka, Y. Wang, and L. Hu
}

\begin{abstract}
The hunger riots that Cameroon experienced in February 2008 were on the one hand a local manifestation of the world food crisis (2007-2008) and on the other hand, a result of ineffective agricultural policies implemented since the 1960s. The analysis of public food security policies in Cameroon from 1960 to 2008, highlights the inability of the latter to fight effectively against food insecurity and to bring Cameroonian agriculture out of the rut. These riots were likely to have a longterm effect on Cameroon's socio-economic trajectory. Because they were food for thought for the Cameroonian government, which ended up realizing that the constraints facing agricultural development felt an immediate need for solutions after the end of the riots. The post-riot strategies implemented by the Cameroonian government boil down to all the measures taken to stem the impact of the crisis and allow food security to all social strata. However, these economic redistribution strategies adopted by the Cameroonian government to allow the poorest to have access to food at an affordable price still fail to stem the situation. Literature relating to the riots of February 2008 in Cameroon abounds, but little is concerned with the analysis of the causes and post-riot government strategies, which is very crucial to understanding the origins of the problems facing the Cameroonian agricultural community today. This article examines the distant and immediate causes of the February 2008 hunger riots in Cameroon, including the post-riot strategies implemented by the Cameroonian government to combat food insecurity and the contribution of international partners.
\end{abstract}

Key words - Agricultural policy, Agro-strategy, Cameroon, food security.

\section{INTRODUCTION}

Food insecurity and global poverty pose a virulent threat to humanity today. Adopted in 2015, the United Nations Sustainable Development Goals (SDGs) aim to eradicate them by 2030. Thus, the SDGs took over from the Millennium Development Goals (MDGs), adopted fifteen years earlier by the international community, under the aegis of the UN. In Cameroon, fighting these threats is also a significant concern.

The analysis of food insecurity in Cameroon expresses the paradox of abundance. Indeed, "Cameroon is a country with a solid agricultural potential (...) It is commonly accepted given its privileged geographical location, vast spatial hold, and high physical and human density. This country has been endowed with multiple assets favorable to its economic and social development" [1]. The breadbasket of central Africa,

Published on July 22, 2021.

A. Daka, School of Public Administration, Department of Sociology, Hohai, China.

(corresponding e-mail: dakaanatole ${ }^{\circledR}$ mail.com)

Y. Wang, School of Public Administration, Department of Sociology,
Cameroon, has excellent potential and agricultural diversity to ensure food security. However, the more an economy is dependent on natural resources, the slower its rate of growth and development [2], [3].

The food crisis, which was one of the major causes of the hunger riots of February 2008 in Cameroon, is the mismanagement resulting from the agricultural sector. As Thierry Pouch [4] points out, "who controls and secures access to sources of food supplies removes the potential risk of population revolts." These demands prompted the Cameroonian government to amend its agricultural policies to consider these government crisis and management strategies that have resulted in developing new standards, options, and strategies and assessing their effectiveness. This article seeks to analyze the causes and government strategies to fight food insecurity after the February 2008 hunger riots in Cameroon. To achieve this, it first insists on the global factors of food insecurity across the world, then it exposes the difficulties of Cameroon's agricultural policies as the starting point of the hunger riots of February 2008, and then it analyzes the new impetus of post-riots food security policies in Cameroon and finally, it probes the contribution of international partners in the fight against food insecurity in Cameroon. On the methodological level, this article is based primarily on the analysis of secondary data; Thus decrees, media analyses, official speeches by high personalities of the State, reports, scholarly articles, etc. were reviewed as a basis for our discussion.

\section{THE PROBLEM OF FoOd InSECURITY: THE Key FACTORS OF THE GLOBAL PHENOMENON}

\section{A. General Overview on Theories of Food Insecurity}

Knowledge on food insecurity has given rise to several approaches. For some, food insecurity results from the difficulty of supplying people despite the available resources favorable to self-consumption agriculture worldwide [5]-[9]. They believe that the planet produces enough resources to feed the world, but the problem arises at the level of the agricultural system and the difficulties linked to its production. Here the emphasis is on the resource's distribution. According to the above authors, solving this problem involves agricultural mechanization, improving farming techniques, and strengthening national stocks.

Hohai, China

(E-mail: wangyj73@ @163.com)

L. Hu, School of Public Administration, Department of Sociology, Hohai, China.

(e-mail hlt8179hu@gmail.com) 
Others argue that current food insecurity results from a combination of climate effects, including natural disasters such as drought and fire outbreaks [10], [11]. The latter stresses that food insecurity is developing and changing under climate conditions combined with the political and economic conditions imposed during the colonial period and contemporary neocolonialism.

The third trend finally stipulates that food insecurity results from wild capitalism, which crushes the peasantry of the South and their production by brutally enrolling them in a now neoliberal market circuit. It is the consequence of economic liberalization leading to unfair competition and inflation [12], [13], [8]. It is a neoliberal approach to hunger.

Concerning these approaches, our subject fits, without being confined to it, with the Zieglerian perspective of hunger and conceives food insecurity as a human construction.

\section{FOOD INSECURITY: A HUMAN CONSTRUCTION?}

Statistics clearly show that the world food insecurity situation has worsened over the years. There are 2 billion people affected by hunger worldwide today. Added to this are 10 million who die each year. The situation is made all the more alarming by the fact that every six seconds a child dies of hunger; 25,000 people die every day from hunger and malnutrition [14]; "1 billion people (that is to say one person in seven) do not eat their fill, while the planet produces enough food for all" (Sofack, 2018, 31). Hunger is ultimately the number one killer in the world [15].

Hunger, which is ravaging people worldwide, is not only the result of insufficient food resources; it is also akin to human construction. Amartya Sen pushes the plug very far by saying that "The world's food problem was not a shortage, apparently, but over-production, leading to low prices and agricultural depression" [16]. Thus, for Madeley, food insecurity comes mainly from adjusting food to international trade rules [17]. Some countries have made food a sordid trade, "a space of interstate rivalries and struggles for control of production" [4]. The search for financial gain has become the ultimate goal at the expense of human well-being. Rejecting a fatalistic thesis of hunger, Bruno Parmentier [18] maintains that it is "essentially a human construction [...] In practice, the victims of hunger are also almost all victims of the greed or indifference of some of their contemporaries". This, moreover, evokes the contemporary market game dominated by agri-food trusts and the bioethanol industry whose frantic quest for profit generates deregulation of the lifestyles and eating habits of the poor, especially those of the southern countries through a policy of global significance against a background of westernization of the world [12]. In this realm of "neoliberalism crusaders," the international economic and market institutions, in this case, the IMF, the WB, and the WTO are the "riders of this apocalypse." Based on the fight against food insecurity, their official discourse hardly masks the underlying desire to develop a mercantile agriculture that underlies all of their investment [1].

Particularly in sub-Saharan Africa, where, beyond simply providing food, agriculture ensures a "social security" that makes life conviviality among people, educating the young people around the meal and structures a commercial dynamic. Therefore, it is essential to analyze the causes of food insecurity from the logic of intervention of these agro-food firms and all other actors while considering peasant agrarian civilizations.

\section{LOGICAL CRISIS IN THE FIGHT AGAINST FOOD INSECURITY IN CAMEROON}

Cameroonian societies have developed agrarian civilizations specific to their history and adapted their daily practices, traditions, and cultures to ensure their food security. Any initiative which does not integrate this knowledge encounters a priori local resistance because it starts based on a "fundamental misunderstanding": the contradiction between any policy or project vision and the practical knowledge of farmers [19]. Such a misunderstanding, because it obscures local indigenous knowledge, if it is not beneficial, generates tensions that can be dismissed if one has been attentive to the peasant world The conflicts between peasant logic and the logic of programs to fight food insecurity result from the fact that the State of Cameroon has wrested control of the "right to think peasant." It instead offers a service to sentient beings without first having discussed the costs and benefits with them. Farmers are excluded from the development of strategies to fight food insecurity. These are the "social forgotten," the "left behind." They are just invited "to contribute to their development. Development that they will no longer have to invent but only to execute" [20]. By implementing programs to fight food insecurity, the Cameroonian government pursues the objective of food satisfaction to Cameroonian households without exception. The practical rationality of its action is the mechanization of agriculture, which guarantees goods to the population in quantity and quality. However, the authority seems to ignore that excess in agricultural production does not necessarily lead to a food security situation for this population in a given population. The "real issue is not the total availability of food but its access by individuals and families. If a person lacks the means to acquire food, the presence of food on the market is meaningless " [21]. Thus, people can starve in a country full of food and export it [16]. Fighting hunger in rural areas is as much fighting rural poverty as the leading cause. In pursuing the objective of guaranteeing food security to all social strata without discrimination, Cameroon perceptibly produces the opposite of its action: the deterioration of the standard of living of poor peasants with limited exploitative capacity.

\section{THE DifFICUlties OF CAMEROON'S AgRICUlTURAL POLICIES AS A STARTING POINT For THE HUNGER RIOTS OF FEBRUARY 2008}

The food-related social crisis that hit Cameroon in 2008 reveals the disillusionment of Cameroonian agricultural policies. From the 1960s, with President Ahmadou Ahidjo's five-year plans to current strategies to fight food insecurity under president Biya, Cameroonian agricultural management suggests the need for new agricultural policies. To understand the causes of the Cameroonian food slump of 2008, one must look into the agricultural policies of this country between 1960 and 2008. 


\section{A. Ahmadou Ahidjo and the Five-Year Plans}

In the aftermath of independence, the economic context of Cameroon imposed agriculture as a pillar on which to rely to improve the country's economic situation. Given the low cost of its expansion (agriculture requires relatively more minor resources than the industrial sector, for example) and the easy accessibility to the equipment that peasants need to be trained in using and maintaining, agricultural activity possessed for the Cameroonian government an obvious advantage over other sectors in the implementation of an economic development policy. Because it remained practiced by a large part of the population, improving this activity would have more marked effects on the population.

Thus, upon his accession to the supreme magistracy, President Amadou Ahidjo launched the five-year plans to make agriculture the country's economic base [22]. From 1960 to 1986 , five five-year plans were implemented entirely in Cameroon. During the first five-year plan executed between 1960 and 1965, there was talk of doubling GDP per capita in record time. The second plan was devoted to improving the living standard of people in rural areas. The last three plans were reserved respectively for increasing production and agricultural productivity, increasing GDP per capita by at least $5 \%$, and increasing real income per capita to improve Cameroon's image in the 2000s. To this end, during these five five-year plans, more than half of the investments had been intended for directly productive agricultural projects, and a large part of the investments was devoted to rural infrastructure and the rural economy and energy as well. A special place has been given to the agricultural sector [23].

These efforts have contributed in a few ways to improving the food and economic situation of the country, in particular by improving the quality and volume of production, advancing considerably towards food self-sufficiency, and developing cash crops. However, it should also be noted that numerous difficulties have marred the smooth running of these plans. These difficulties led to an intense stagnation in the 1980 s.

Indeed, from 1969 to 1980, agriculture grew harmoniously and accounted for 30\% of GDP. From 1982 until 1985, overall growth declined. This deceleration is mainly due to the decline of the food sector (Table 1). This sector has experienced a marked break from the previous period. The food crop on which Cameroon's agricultural growth was based collapses by approaching zero growth, a decline of more than $3 \%$ in production per capita, without the export sector taking over. The latter continues its growth based on $2 \%$ per year (Table 1). The second half of the 1980s thus characterized the end of an accelerated growth cycle resulting in a decline throughout agricultural production. This leads to a decrease in per capita production over the period reducing the coefficient of food self-sufficiency.

TABLE I: LOWER AGRICULTURAL GROWTH RATES AND LOWER RATES OF

\begin{tabular}{cccc}
\multicolumn{4}{c}{ FoOD SELF-SUFFICIENCY BETWEEN 1968 AND 1985 } \\
\hline \hline Period & $1968-1976$ & $1977-1981$ & $1982-1985$ \\
\hline Food crop & 4 & 13.5 & 0.1 \\
Cash crop & 1.9 & 2.9 & 2.1 \\
Agricultural in general & 4.3 & 14.2 & 8.1 \\
\hline \hline
\end{tabular}

Moreover, the dynamics of the effort rested only on the State apparatus, favored the emergence of an authoritarian State, rigid, inflexible, and hostile to private initiatives. These agricultural policies have favored cash crops to the detriment of food crops. This marginalization of food crops has inevitably led to failure to achieve food self-sufficiency because food security is to have a diversified diet in sufficient quantity. Moreover, "the failure of all these strategies can be explained by a planning process which in practice only concerns technocrats and politicians, excluding producers" [1].

\section{B. Paul Biya and Initiatives under Constraints}

Having come to power during a period characterized by the failure of the five-year plans, the decline in production, a relative food and economic crisis, Paul Biya was forced to adopt and set up under the aegis of the Bretton Woods institutions (IMF and WB), a multitude of reforms such as the Agricultural Sector Adjustment Plan (ASAP) in 1994, the National Participative Development Program (NPDP), the New Agricultural Policy (NAP) [1]. From these initiatives emerged many programs and projects whose primary goal is to control the country's food security and implement an excellent agricultural development policy. It is in this context that we witnessed the establishment of the National Agricultural Extension and Research Program (NAERP), the sectoral strategy for animal husbandry, fisheries, and animal industries, the Poverty Reduction Strategy Document (PRSD), and the Rural Sector Development Strategy Document (RSDSD). They are part of the general State strategy of reducing poverty, improving the regulatory and economic framework for participatory management of the space and natural resources These programs are intended to reduce poverty and improve food security by diversifying the economy, developing rural areas and the agricultural sector, strengthening the private sector, etc. The objective of these programs is precisely to improve rural producers' access to financial markets and promote the management of natural resources to create an effective environment-friendly system [22]. There is also the establishment in 2005 of the National Food Security Program (NFSP) under the supervision of the ministry of agriculture and rural development (MINADER). Despite these attractive initiatives, the disillusionment of the agricultural policies implemented during the reign of Paul Biya is great [1]. Since Cameroon's food production does not allow it to meet all the food needs of its population, it depends mainly on imports, mainly tubers, vegetable oils, cereals ... "External dependence on cereals reached 29\% in 2004 and remained above $25 \%$ in 2008 despite the decline in imported quantities (Table 2). Cameroon is vulnerable to changes in cereal prices on international markets [24].

TABLE II: IMPORT DEPENDENCY RATE (\%) ROOTS AND TUBERS, OILSEEDS, FRUITS FROM 2003 TO 2008

\begin{tabular}{ccccccc}
\hline \hline Years & 2003 & 2004 & 2005 & 2006 & 2007 & 2008 \\
\hline $\begin{array}{c}\text { Roots and } \\
\text { tubers }\end{array}$ & 0 & 0,13 & 0 & 0 & 0 & 0 \\
Vegetable & 8,53 & 15,38 & 7,08 & 26,96 & 8,39 & 10,2 \\
oils & & & 20,7 & & 8 \\
Cereals & 22,6 & 29,39 & 8, & 19,75 & 25,8 & 27,3 \\
& 6 & & 0,29 & 0,57 & 0,33 & 0,32 \\
Vegetables & 0,31 & 0,43 & 0,37 \\
\hline \hline
\end{tabular}


The collateral damage of the structural adjustment programs caused the State's disengagement from the productive sector (abolition of subsidies, liberalization of the trade) and exposed Cameroonian peasants to the implacable laws of the market. The State's withdrawal from the agricultural sector has led to the dismantling of the production support systems, the lack of agricultural management, and the transfer of specific development activities to the private sector or too young producer groups. The role of the State is reduced here to simple control [25]. However, the root cause of this failure is found above all in "the chronic neglect of a bureaucracy. It is struggling to improve the living conditions of its population [23].

C. The February 2008 Hunger Riots in Cameroon: A Demonstration against Expensive Living and the Restriction of Public Freedoms

Analysis of agricultural policies implemented in Cameroon since 1960 shows that government investments have boosted the agricultural sector. However, the inadequacy of these policies with the constraints of the moment resulting from the destabilizing effects of the Structural Adjustment Programs (SAP) has inevitably led to demonstrations. The 1980s economic crisis that shook Cameroon and all other African countries resulted in the State's withdrawal from specific sectors of activity. Because of the international economic situation, Cameroon was compelled by the Bretton Woods institutions to adopt the Structural Adjustment Programs (SAPs) to get its economy back on track. Being unable to ensure national development, the State, which was the only guarantor, lost interest until then. Faced with the noninvolvement of the State and the impact of the adverse effects of the SAPs on local activities, family farming which is the core foundation of food security in Cameroon, collapsed. The 2008 food crisis helped bring it back to the spotlight and showed the need for Cameroon to find adequate responses that could ensure food security, address rural poverty and provide jobs for a population mainly made up of youth. Therefore, this crisis (demonstration) was a prominent expression of Cameroonian's dissatisfaction against social injustice, restriction on public freedoms, the costly life, and the exponential rise in necessities (Fig. 1).

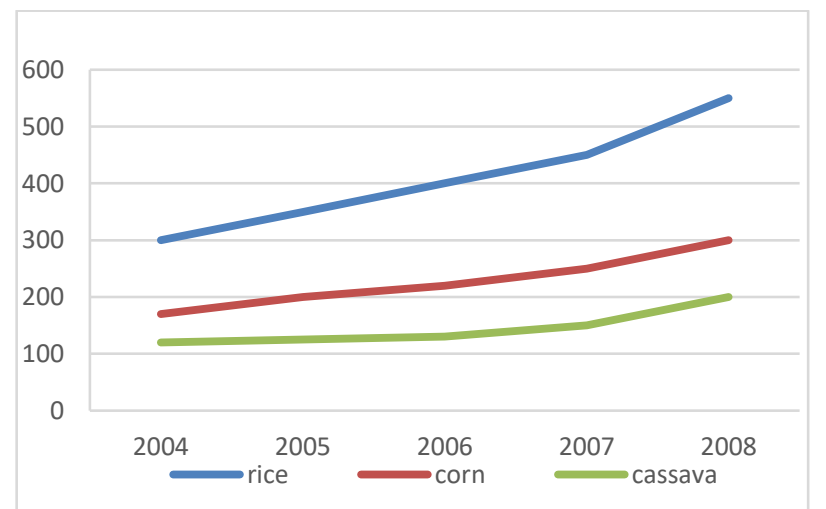

Fig. 1. Evolution of food prices (in CFA $/ \mathrm{kg})-1$ United States Dollar $=$ 585.58FCFA

This unpleasant new socio-economic and political context in a governance system that is itself obsolete [26] led some observers to believe that "all the ingredients were there to set the powder on fire" [1]. The decree signed by the governor of the Littoral region banning public demonstrations has "exacerbated and rekindled the discontent of a large segment of the population" [27]. However, the increase in fuel price, various fines, excessive parking taxes, losses of insurance campaigns, etc., started the strike of the transporters and logisticians and, from there, the riots of hunger.

The early stage of this movement of transporters was echoed by the young and the urban poor, exposed to a process of impoverishment, accelerated for a long time. Being the most affected by this crisis because of being forced to depend exclusively on monetary income to meet their food needs, they demonstrated against the expensive life and against the opulence of a certain elite which clings to power despite the mediocrity in public affairs management [28].

All this constitutes a process of putting individuals under tension [25]. These riots are "the ultimate expression of the desperation of a population caught in the throat by a tough social and economic situation for the past fifteen years" [23]. They consecrate to speak against the bankruptcy of the Cameroonian State, which has failed to build a favorable environment for the social and economic development of its population. However, these riots would have allowed Cameroon to rethink its agro-strategic governance and better its public food security policies.

\section{RELAUNCHING FoOD SECURITY POLICIES IN} CAMERoOn AFTER THE Hunger Riots OF FEBRUARY 2008

Cameroon's post-riot agricultural policies boil down to all the measures taken to stem the effect of the crisis and enable food security for all social strata. It will be a question for us here to analyze the contours and the effectiveness of these measures.

\section{A. The Mission of Regulating Supplies and Consumer Products (MIRAP)}

Within the framework of the improvement of the agrostrategic governance post-riot of his country, President Paul Biya on February 1, 2011, created the mission of regulating the supplies and consumer products [29]. This structure has the ambitious responsibility of contributing to the fight against the high cost of living after the food crisis of 2008 .

Placed under the technical and financial supervision respectively of the Ministry of Trade and the Ministry of Finance, the MIRAP is a structure for alerting, purchasing, importing, and storing consumer goods in order to supply the Cameroonian market with good quality foodstuffs and in their best conditions. The creation of this structure is part of the Cameroonian State's strategy for food sovereignty. Thus, in its balance sheet after a few years of existence, "it identified 220 periodic witness markets across the national territory, more than 10,000 tones of consumer products, 2.7 billion FCFA of transactions including 1.9 billion for only agropastoral producers" [1]. However, this structure concealed failures that compromise its functioning.

Through its missions, MIRAP is a structure with laudable ambitions. However, some analysts think that these missions are contradictory and unrealistic. In fact, at the agro-pastoral show in Ebolowa (southern region), President Paul Biya had promised to reduce the very high volume of food imports in 
order to ensure the country's food sovereignty. However, the supply of widely consumed food products to be supplied by MIRAP must be imported. "Also, the limits of this structure were immediately noted because access to consumer products will remain a challenge for all households" [1]. Indeed, rice, corn, sugar, chicken, etc. are at higher prices out of reach for ordinary people [30].

\section{B. Promotion of Second-Generation Agriculture}

President Biya unveiled his policy for second-generation agriculture at the agro-pastoral show in Ebolowa in 2011. This meeting of rural world actors, which was supposed to be the revival of the agricultural policy of Cameroon, was held under the theme, "Producing better: the guaranteed march towards the emergence of Cameroon by 2035". It is a question of paying particular attention to the development of rural areas. By promoting second-generation agriculture, Biya is thereby attesting that agriculture plays a vital role in the development process of his country. In his inaugural speech, he expressed the need to make every effort to ensure food security and create jobs in rural areas so that Cameroonian agriculture, in the broad sense, plays its driving role in the national economy [31]. It is about developing a new strategy that must start from production to consumption through marketing. They must now count on programs adapted to the requirements of intensive and sustained production. "This agricultural revolution announced by President Paul Biya was thus conceived as a set of measures intended to get the agricultural sector out of the rut" [1].

Nevertheless, ten years after the much-acclaimed promise of second-generation agriculture at the Agropastoral show in Ebolowa, almost no concrete action has been taken to implement this agricultural policy. The question then arises as to the feasibility of this project, which has won overall Cameroonians. Indeed, one wonders if second-generation agriculture is not a simple mirage-like other slogan [1]. In all cases, "the feeling that emerges from this media coup is that for the sake of populism, the leader of the ruling oligarchy was trying to calm the impatience of the masses by serving them, as a tremendous agricultural ambition, a mobilizing utopia" [32]. Second-generation agriculture has also suffered the same fate as almost all of the agricultural innovations experienced in Cameroon before it: which is a failure.

\section{Other Strategies to Fight Food Insecurity in Cameroon}

Apart from the strategies mentioned above, Cameroon has adopted a set of strategies both at the national and international levels to stem the effects of the crisis and give a new orientation to the agricultural economy [33].

At the national level, the strategy mainly concerns implementing agricultural development projects and programs by MINADER. More than 54 Public Investment Budget (BIP) / MINADER-funded projects have been implemented by the Cameroonian government to develop the agricultural sector, improving productivity, and ensuring food security. An agricultural bank was created for this purpose "to solve the problem of financing agriculture and decapitalization of the rural environment" [1].

At the supranational level, the first effort was to adopt the Strategy Document for Growth and Jobs (SDGJ) in 2009. This document is the unifying framework of all sectoral development policies, which grants a prominent place to agriculture to accelerate growth and bring it to double digits by 2020 .

The Comprehensive Africa Agriculture Development Program (CAADP) and the agricultural investment plan (AIP) have also been adopted by the Cameroonian government [34] to accelerate the modernization of agriculture, enhance agricultural growth and reverse the trend of inflation by developing Cameroon's agricultural potential [35].

In the same perspective, all African states set up the acropolis program to promote food self-sufficiency by producing essential agricultural products and promoting agro-industrial development [36]. More than 44 acropolises are thus created in Cameroon in breeding, fishing, agriculture, etc.

However, implementing all these strategies did not allow Cameroon to reduce the volume of food imports. Cameroon's agriculture before and after the hunger riots of February 2008 suffered from structural problems. The results achieved in implementing successive agricultural policies are still below expectations because the production of export crops and food crops remains inadequate. The cereal deficit has increased over the years. It increased from 565,000 tones to 682,000 tones, an increase of $20.7 \%$ (Table 3). Cameroon spent CFAF 550 billion on food imports in 2009, 7 times more than in 1994 (WFP, 2011, 42).

TABLE III: GROWTH OF THE CEREAL DEFICIT AND THE VOLUME OF

\begin{tabular}{ccccccc}
\multicolumn{7}{c}{ IMPORTS (THOUSANDS OF TONS) } \\
\hline \hline Years & 2006 & 2007 & 2008 & 2009 & 2010 & 2011 \\
\hline $\begin{array}{l}\text { Cereal } \\
\text { deficit }\end{array}$ & 565 & 587 & 633 & 645 & 640 & 682 \\
Import & & 542 & 698 & 720 & 745 & 710 \\
\hline \hline
\end{tabular}

From this analysis, it emerges that Cameroon is unable to feed itself. To address this critical issue, its international partners regularly come to its aid.

\section{THE SUPPORT OF INTERNATIONAL PARTNERS IN THE FIGHT AGAINST FOOD INSECURITY IN CAMEROON}

In the fight $\mathrm{c}$ against food insecurity, Cameroon most often seeks the help of its international partners, also called "international support actors" [33] Their help is varied and is deployed on several levels.

\section{A. United Nations Agencies}

These are mainly the Food and Agricultural Organization of the United Nations (FAO), the World Food Program (WFP), the International Fund for Agricultural Development (IFAD), etc. They have engaged in strategic partnerships with the Cameroonian government, such as the global food security cluster, the international alliance against hunger, and the coordination of many other activities. The intervention of these UN institutions in Cameroon is part of the support for national priorities in sustainable rural development.

The signing of the framework agreement between the Cameroonian government and the WFP on July 15, 2008, is in line with this strategic partnership, which guarantees food security in the country's Far North and North regions. In the same vein, IFAD provides $\$ 19.2$ million in loans to 
Cameroon to improve food security in rural areas. Through this gesture, IFAD aims to increase the production of rice and onions, improve their conservation, processing, and marketing, and strengthen the technical and organizational capacities of small producers. The increase in agricultural production should reduce food imports and increase exports.

\section{B. Other International Institutions}

Cameroon has several institutional partners in the fight against food insecurity and rural poverty. However, we will focus here on the case of the Sustainable Development Council (C2D) and the European Development Fund (EDF).

Between 2000 and 2008, EDF investments in rural development, agriculture, livestock, and fishing in Cameroon amounted to almost 100 million euros [33]. This European Union (EU) subsidiary instrument contributes to food security in Cameroon through support for the various strategies put in place by the government. It most often intervenes in the framework of strategies designed by the DSCE, SDSR, PNIA, CAADP-NEPAD to improve the conditions of rural populations, ensure food security, promote entrepreneurship in the agricultural sector, and improve the productive framework of these latest [37].

The C2D is an institution of the French Development Agency that supports Cameroon in promoting food security and rural development. It is specifically involved in strengthening public services provided to rural producers by providing advice and funding investment projects. Its various programs strengthen Farmers' Organizations (FOs), the management of State agricultural policies, and the capacity for equipment and access to finance for local authorities. It wants to be the secular arm of the Cameroonian government in the sense that it supports MINADER and MINEPIA in achieving their objectives.

\section{CONCLUSION}

Ultimately, food security is a question that polarizes the debate at the global level and is at the center of the structuring of contemporary international relations dominated by the neoliberal market. The commercialization of agriculture produces an international bourgeois class which monopolizes surplus value, thus creating a poor class in a situation of permanent food insecurity. The analysis of the food crisis of February 2008 in Cameroon shows that it is the result of social injustice and an agro-strategic governance crisis. These riots are both the result of decades of cumulative frustration and the unexpected eruption of a hitherto sluggish volcano. No particular sign made it possible to glimpse these collective mobilizations which arose in Cameroon's cities that month. So, what happened for such an uprising to take place in February 2008, when the populations were already living the horrors of spectacular impoverishment and the inevitable revival of the regime led by Paul Biya? It's a random combination of factors that explains why the decades-long blaze has propelled the blanket covering national frustrations. In reality, the various public food security policies in Cameroon from 1960 to 2008 reflect the state's inability to effectively fight food insecurity and bring Cameroon's agriculture out of the rut. The economic redistribution policies adopted by the Cameroon's government to allow the poorest access to food at an affordable price have for the most part not been implemented successfully. This slump finally resulted in a popular demonstration in February 2008. The post-riot attempts by the Cameroon's government to resolve this crisis have remained unproductive. And even the support of international partners does not seem to solve this problem. It is therefore up to the Cameroon's government to develop an effective agricultural governance strategy capable of integrating the populations from below.

\section{REFERENCES}

[1] N. Sofack, Nouvelle géopolitique de l'agriculture et de l'alimentation: quelles politiques publiques de sécurité alimentaire au Cameroun? Paris: L'Harmattan, 2018.

[2] J. D. Sachs and A. Warner, "Natural Resource Abundance and Economic Growth," National Bureau of Economic Research, Inc, NBER Working Paper 5398, Dec. 1995. Accessed: Jun. 12, 2021. [Online]. https://econpapers.repec.org/paper/nbrnberwo/5398.htm.

[3] J. D. Sachs and A. M. Warner, "The curse of natural resources," Eur. Econ. Rev., vol. 45, no. 4, pp. 827-838, May 2001, doi: 10.1016/S00142921(01)00125-8.

[4] T. Pouch, La guerre des terres: stratégies agricicoles et mondialisation. Paris: Choiseul, 2010.

[5] F. de Ravignan, La faim, pourquoi?: un défi toujours d'actualité. Paris La Découverte : Syros, 2009.

[6] J. Y. Carfantan and C. Condamines, Vaincre la faim, c'est possible. Paris: Éditions du Seuil, 1983.

[7] J. Ziegler, Betting on famine: why the world still goes hungry. New York: New Press, 2013.

[8] J. Ziegler, La faim dans le monde expliquée à mon fils. 2015.

[9] S. Bessis, La faim dans le monde. Paris: La Découverte, 1991.

[10] J. Copans, Ed., Sécheresses et famines du Sahel. Paris: F. Maspero, 1975.

[11] A. Guichaoua, Destins paysans et politiques agraires en Afrique centrale. Paris: L'Harmattan, 1989.

[12] S. Latouche, L'occidentalisation du monde: essai sur la signification, la portée et les limites de l'uniformisation planétaire. Paris: La Découverte, 1989.

[13] M. Eldin and P. Milleville, Eds., Le Risque en agriculture. Paris Editions de l'ORSTOM, 1989.

[14] U. Nations, "Losing 25,000 to Hunger Every Day," United Nations https://www.un.org/en/chronicle/article/losing-25000-hunger-everyday (accessed Jun. 12, 2021).

[15] J. Feyder, La faim tue. Paris: Harmattan, 2011.

[16] A. Sen, Poverty and famines: an essay on entitlement and deprivation. Oxford : New York: Clarendon Press ; Oxford University Press, 1981.

[17] J. Madeley, Hungry for trade: how the poor pay for free trade. London; New York: New York: Zed Books ; Distributed in the USA exclusively by St. Martin's Press, 2000.

[18] B. Parmentier, Faim zéro - En finir avec la faim dans le monde, La Découverte. Paris: La Découverte, 2014.

[19] J. P. O. de Sardan, "Sciences sociales africanistes et faits de développement," in Paysans, experts et chercheurs en Afrique noire. Sciences sociales et développement rural, Paris: Karthala: CIFACE, 1985, p. 224.

[20] M.-C. Gueneau and B. J. Lecomte, Sahel: les paysans dans les marigots de l'aide. Paris, France: Harmattan, 1998.

[21] G. Azoulay and J.-C. Dillon, La sécurité alimentaire en Afrique: manuel d'analyse et d'élaboration des stratégies. Paris: ACCT [u.a.], 1993.

[22] H. Mbouri Mbak, "La production alimentaire au Cameroun," in Traité sur la sécurité alimentaire au Cameroun, Areion Publishing., Paris: Areion Publishing, 2002.

[23] A. Z. Tamekamta and J. K. Menkene, Eds., L'urgence d'une révolution agricole au Cameroun. Paris: L'Harmattan, 2013.

[24] WFP, "Cameroon Comprehensive Food Security and Vulnerability Analysis April/May 2011 - Cameroon," ReliefWeb, 2011. https://reliefweb.int/report/cameroon/cameroon-comprehensive-foodsecurity-and-vulnerability-analysis-aprilmay-2011 (accessed Jun. 12 2021).

[25] P. Janin, L'avenir des planteurs camerounais: résister ou se soumettre au marché. Paris, France: Karthala, 1999.

[26] MINEPAT, “Autosuffisance et sécurité alimentaires au Cameroun: Une analyse basée sur la flambée des prix des Produits alimentaires de 
première nécessité - PDF Téléchargement Gratuit.” https://docplayer.fr/21527521-Autosuffisance-et-securitealimentaires-au-cameroun-une-analyse-basee-sur-la-flambee-des-prixdes-produits-alimentaires-de-premiere-necessite.html (accessed Jun. 12, 2021).

[27] J.-C. Edjangue, Cameroun: un volcan en sommeil. Paris: Harmattan, 2010.

[28] M. Merino, "L’insécurité alimentaire en Afrique subsaharienne»," Fondation pour la Recherche Stratégique, vol. 02, no. 09, p. 9, 2009.

[29] Republic of Cameroon, "Cameroon: Creation, organization and functioning of the Mission for the Regulation of the Supply of Consumer Products," Camerlex, Nov. 16, 2012 https://www.camerlex.com/cameroun-la-creation-l-organisation-et-lefonctionnement-de-la-mission-de-regulation-des-approvisionnementdes-produits-de-grande-consommation-13606/ (accessed Jun. 13 , 2021).

[30] S. Chauvin, "Cameroun : les enjeux de la croissance," MacroDev, pp. 1-28, 2012.

[31] P. Biya, "Speech by the President of the Republic, H.E. Paul Biya on the occasion of the opening ceremony of the agro-pastoral fair of Ebolowa," 2011. https://www.prc.cm/fr/actualites/discours/1639discours-du-president-de-la-republique-s-e-paul-biya-a-l-occasion-dela-ceremonie-d-ouverture-du-comice-agro-pastoral-d-ebolowa (accessed May 26, 2021)

[32] J. Koufan Menkene and M. EbeneNyamnding, "De l'urgence agricole plaidoyer pour l'agriculture de seconde génération," in L'urgence d'une révolution agricole au Cameroun, "Émergences africaines, L'Harmattan., Paris, 2013.

[33] P. Mvogo and G. Manga, "Les acteurs d'appoint internationaux," in Traité sur la sécurité alimentaire au Cameroun, Areion Publishing. Paris, 2013.

[34] C. Che, "The Comprehensive Africa Agriculture Development Programme and the Fight Against Poverty - By Chofor Che - African Liberty," African Liberty, 2013. https://www.africanliberty.org/2013/07/22/the-comprehensive-africaagriculture-development-programme-and-the-fight-against-povertyby-chofor-che/ (accessed Jun. 13, 2021).

[35] Cameroun Tribune, "Plan national d'investissement agricole du Cameroun a été validé mercredi (...) - Le Hub Rural." http://www.hubrural.org/Plan-national-d-investissement.html (accessed Jun. 13, 2021).

[36] Republique du Cameroun, "Programme agropoles Cameroun," 2016. https://programme-agropoles.cm/ (accessed Jun. 13, 2021).

[37] AFD, "Améliorer la situation alimentaire des populations les plus vulnérables d'Afrique de l'Ouest | AFD - Agence Française de Développement," L'Agence Française de Développement. https://www.afd.fr/fr/carte-des-projets/ameliorer-la-situationalimentaire-des-populations-les-plus-vulnerables-dafrique-de-louest (accessed Jun. 13, 2021)

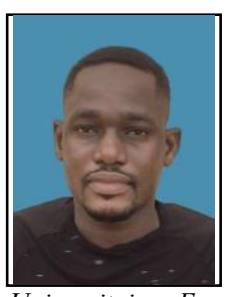

A. Daka was born in 1988. Daka holds a master's degree in rural sociology from the University of Ngaoundéré, Cameroon. He completed this program in 2015.

Anatole is a young researcher who is interested in agricultural cooperation between China and Cameroon, agricultural development and farmers' organizations.

Anatole published a book in 2018 by Editions Universitaires Européennes on peasant dynamics in the cotton zone of Lam in North Cameroon. He published also two scientific articles which respectively deal with scientific research in sub-Saharan Africa and adaptation strategies of farmers to new methods of supervising cotton producers in North Cameroon. He is currently a $\mathrm{PhD}$ candidate in sociology at the School of Public Administration at Hohai University in China.

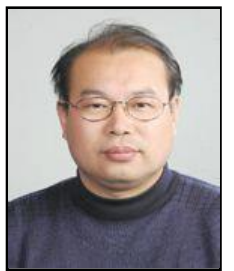

Y. Wang was born in 1973. He obtained his $\mathrm{PhD}$ degree in sociology from Nanjing University. He is Vice-Dean of School of Public Administration, Director of the master's in social work education and Research Center and Director of the Research Center for Social Survey.

Prof. Wang is qualified to supervise doctoral students. He is one of the "young and middle-aged science and technology leaders" in 333 High-level Talent Training Project in Jiangsu Province. His main research interests are social change in rural areas, migration, analysis of organizations and institutions. He conducted numerous research projects, including two sponsored by the National Social Science Fund. He published two books and more than 40 articles on the professional mobility of migrant workers and their children, their willingness to settle in the city, mental health, social communication, social identification and integration. His studies have already won several awards. For example, his book, Migrant Children and Their Acculturation in Cities, won a Third Class Philosophical and Social Research Award from the Ministry of Education of Jiangsu Province.

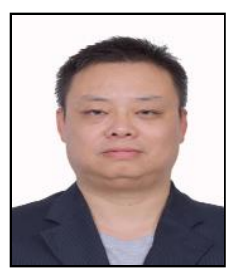

L. Hu was born in 1978. He obtained his $\mathrm{PhD}$ degree in sociology from Shanghai University. He is qualified to supervise master's students. He was a visiting scholar at the University of California at Los Angeles (April 2016 to April 2017). His main research interests are cultural anthropology and rural sociology.

Pr. Hu is leading several projects, including "A Sociological Analysis of Property Rights Problems in Rural Land Transactions" (2009), sponsored by the National Social Science Fund, and "A Sociological Analysis of Property Rights Problems in Forest Transactions" (2003), sponsored by the National Postdoctoral Fund. He also published a book, Analyzing Property Rights from a Cultural Perspective, and several articles. 